\title{
Phytobiotic Activity of Piper Auritum and Ocimum Basilicum on Avian E. Coli
}

http://dx.doi.org/10.1590/1806-9061-2019-1167

\section{-Author(s)}

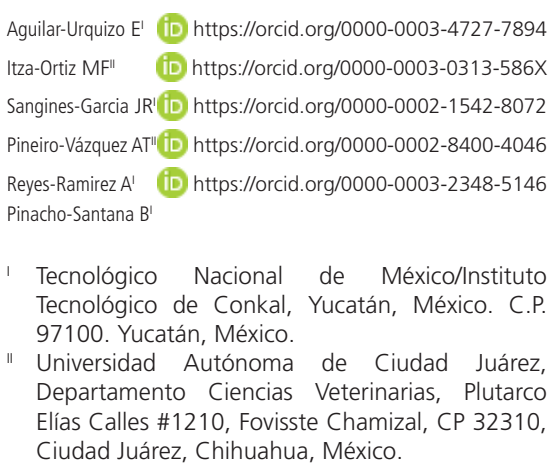

Aguilar-Urquizo E' iD https://orcid.org/0000-0003-4727-7894 Itza-Ortiz MF" (iD https://orcid.org/0000-0003-0313-586X Sangines-Garcia JR' (iD) https://orcid.org/0000-0002-1542-8072 Pineiro-Vázquez AT" (iD) https://orcid.org/0000-0002-8400-4046 Reyes-Ramirez A' (iD https://orcid.org/0000-0003-2348-5146 Pinacho-Santana $\mathrm{B}^{\prime}$

Tecnológico Nacional de México/Instituto Tecnológico de Conkal, Yucatán, México. C.P. 97100. Yucatán, México.

" Universidad Autónoma de Ciudad Juárez, Departamento Ciencias Veterinarias, Plutarco Elías Calles \#1210, Fovisste Chamizal, CP 32310 Ciudad Juárez, Chihuahua, México.

\section{-Mail Address}

Corresponding author e-mail address Mateo Itza-Ortiz

Universidad Autónoma de Ciudad Juárez, Departamento Ciencias Veterinarias,

Plutarco Elías Calles \#1210, Fovisste

Chamizal, CP 32310, Ciudad Juárez,

Chihuahua, México.

Phone: +52 (656)6881800

Email: mateo.itza@uacj.mx

\section{- Keywords}

Colibacillosis, phytobiotic, Piper auritum, Ocimum basilicum.

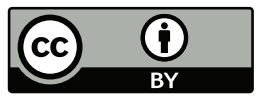

Submitted: 16/August/2019

Approved: 10/December/2019

\section{ABSTRACT}

Natural antimicrobials, known as phytobiotics, are used in bacterial infections. The objective of this study was to evaluatethe phytobiotic activity, in vitro and in vivo, of an extract and an essential oil of Piper auritum and Ocimum basilicum on avian Eschericia coli serotype $\mathrm{O} 2$ in broiler chickens experimentally infected. For the in vitro test, extracts at $4,8,12$ and $16 \%$ in water-based solvent or alcohol at $70 \%$ were prepared from leaves of both plants. In the essential oils, solvents at $10 \%$ were used. A concentration of $1 \times 10^{8} \mathrm{CFU} \mathrm{mL}^{-1}$ of bacteria was seeded and on each sense disc, $25 \mu \mathrm{L}$ of the extract or essential oil were poured, except on the positive or negative control. The diameter of the inhibition zone (DIZ) of bacterial growth was measured. In the in vivo test, 40 chickens were inoculated, by intratracheal route, with a bacterial suspension of $1 \times 10^{8} \mathrm{CFU} \mathrm{mL} \mathrm{m}^{-1}$. E. col was identified and isolated from the organs; mortality, morbidity and relative weight of the organs were measured, and postmortem lesions and histopathologic findings were observed. A completely randomized design and the Kruskal-Wallis test for data analysis was used. By increasing the concentration of the extract, DIZ was greater; at the time of slaughter, differences in body weight $(p<0.05)$ were found and the majority of lesions were observed in lungs. It is concluded that leave extracts of $P$. auritum and $O$. basilicum had phytobiotic activity on $E$. col serotype $\mathrm{O}$ 2.

\section{INTRODUCTION}

It is calculated that about 100,000 plants produce secondary metabolites (Dixon, 2004) and the biological activity of some of them is well known (Gurib-Fakim, 2006). These plants are used without restriction, in dose or age of the animal, in the form of extracts or essential oils, as an alternative to growth promotive antimicrobials (AGP), due to their capacity to elevate digestive enzyme activity (Adebolu \& Abiola, 2005), nutrient absorption, increase in food intake (Chávez et al., 2015), reduction in undesirable bacterial population (Acosta et al., 2003), decreased intestinal activity associated with lymphatic system and increased precaecal digestion of nutrients; generally reflecting greater intestinal flora balance (Witte, 2000; Windisch et al., 2008).

Some plants or part of them contain natural antimicrobials that are known as phytobiotics, these types of antimicrobials are considered as potentially safe sources (Griggs \& Jacob, 2005; Rodríguez, 2011). This activity has been associated with secondary metabolites, such as: carvacrol, thymol, eugenol, safrole, perillaldehyde, cinnamaldehyde, $\alpha$ terpineol, linalool and cinnamic acid (Lataoui \& Tantaoui-Elaraki, 1994; Consentino et al., 1999; Burt, 2004; Burt et al., 2005). Other reported components are borneol, $\gamma$-terpinene and $p$ cymene that have a synergic or antagonic activity (Consentino et al., 1999; Vardar-Ünlü et al., 2003). 
Aguilar-Urquizo E, Itza-Ortiz MF, Sangines-Garcia JR, Pineiro-Vázquez AT, Reyes-Ramirez A, Pinacho-Santana B
Phytobiotic Activity of Piper Auritum and Ocimum Basilicum on Avian E. Coli
Escherichia coli is a normal habitant of the intestine of birds and can remain for a long time in poultry farms (Cortes, 2008; García-Compean et al., 2011) without causing any adverse effect, since it generally responds to a secondary infection subsequent to a Mycoplasma sp first attack and particularly by the infectious bronchitis virus, which is a predisposing factor of colibacillosis (Cook et al., 1991; Nakamura et al., 1999) or even micro environmental due to high concentrations of ammoniac, $\mathrm{CO}_{2}$ or dust; the latter damages the cilia of the respiratory tract, causing colibacillosis, the main cause of condemned carcasses and considered as potential public health problem (Dozois et al., 2000; Mellata et al., 2003; García-Compean et al., 2011).

Among $E$. coli properties there is the belonging of specific serotypes such as: $01: K 1,02: K 1,35$ and 078:K80 (Dho-Moulin \& Fairbrother, 1999; Ewers et al., 2003) being serogroups $\mathrm{O} 2$ and $\mathrm{O} 78$ responsible for $80 \%$ of the infections caused by colibacillosis in the field (Dho-Moulin \& Fairbrother, 1999; Horne et al., 2000; Ewers et al., 2003; Blanc et al., 2007). Up to date, bacterial resistance to antimicrobials is already known, due to its uncontrolled use (Kalra, 1998; Kalemba \& Kunicka, 2003).

The genus Piper contains approximately 1500 species, with nearly 1000 species in tropical America. It has been widely studied for being an important source of bioactive components, with antimicrobial properties for human, plants and animals (Dorman \& Deans, 2000; Kato \& Furlan, 2007; Regasini et al., 2009; Monzote et al., 2010).

Piper auritum belongs to Piperaceae family. It is native to Mexico and is widely distributed in tropical America (Roig, 1988). Valsara (1994) and Oudhia (2003) demonstrated that this plant has antiseptic, antifungic and antioxidant effect, the latter is very near to the reported for $\alpha$-tocopherol (Ramya et al., 2010). The chemical analysis of the essential oil of Piper auritum reveals that safrole is its main component, occupying about 70 to 90\% (Gupta etal., 1985; García et al., 2007; Sánchez et al., 2009). Besides safrole, the essential oil of Piper auritum contains about 40 substances in lower amount, such as: thymol, carvacrol, myristicin, linalool, borneol, camphor, cineol, methyl eugenol and a wide variety of benzene components (Domínguez et al., 1962; Oliveira et al., 2004).

The genus Ocimum $L$. is formed by about 30 species, 16 of which are native to Africa. Its distribution area goes from tropics to subtropics of America and Europe (Mahabir, 1995). It has antimicrobial and spasmolytic properties (Acosta et al., 2003; Ramya et al., 2010). The reported active components of $O$. basilicum, basilicum variety are: linalool (54.28\%), 4- allylanisole (26.50\%), eugenol (9.54\%), 1.8 cineol $(4.21 \%)$ and for purpurascens variety are: E-methyl cinnamate $(55.95 \%)$, linalool $(21.30 \%)$, Z-methyl cinnamate $(16.85 \%)$ and 1.8 cineol $(1.44 \%)$, besides having phenolic acids derived from cinnamate acid and flavonoids (Acosta et al., 2003). Roldán et al. (2010) indicate that the largest components of $O$. basilicum are: $\beta$-linalool (46.67\%) and estragole (27.43\%).

The objective of this study was to evaluate the phytobiotic activity of the extract and essential oil of Piper auritum and Ocimum basilicum, first in vitro determining the diameter of the inhibition zone of bacterial growth and in vivo, in the productive performance, bacterial growth, relative weight of organs and histopathologic findings in broiler chickens experimentally infected with avian Escherichia coli serotype $\mathrm{O} 2$.

\section{MATERIAL AND METHODS}

\section{Collection of samples and storage.}

The leaves of Piper auritum and Ocimum basilicum were recollected in the Unidad de Producción e Investigación Agrícola y Pecuaria of the Instituto Tecnológico de Conkal. The leaves were dried in a forced air oven at $60^{\circ} \mathrm{C}$ for 24 hours; subsequently, they were milled in order to obtain flour from the leaves using a sieve size of $1 \mathrm{mM}$ thickness. The experiment consisted of two tests, the first was in vitro and the second in vivo.

\section{In vitro test}

\section{Preparation of aqueous extract}

Four, eight, twelve and sixteen grams of flour from leaves of each plant were weighed, submerged in 100 $\mathrm{mL}$ of boiling distilled water and underwent decoction for 15 minutes, and then was filtered using a cloth of linen (López-Casamayor, 2007). Once the extract was cooled it was filtered again using Whatman paper number 2 (López-Casamayor, 2007).

\section{Preparation of alcoholic extract}

Four, eight, twelve and sixteen grams of flour from the leaves of each plant were weighed and submerged in $100 \mathrm{~mL}$ of alcohol at $70 \%$. The solutions were agitated using a hot plate stirrer (IKA, C-MAG-HS7, North Carolina, USA) for 15 minutes and allowed to sit for 48 hours at room temperature. Extracts were first filtered using a cloth of linen (López-Casamayor, 2007), followed by centrifugation at 7000 rpm for 10 minutes 
using a centrifuge (Beckman TJ-6, Illinois, USA); the supernatant was filtered using a Whatman paper number 2 (Mamoru et al., 1996; Tequida-Meneses et al., 2002). Both extracts were poured into amber glass bottles and stored in the refrigerator. At the time of use they were sterilized by filtration using Millipore membrane of 0.8 to $0.2 \mu \mathrm{M}$ (López- Casamayor, 2007).

\section{Obtaining essential oils}

Forty grams of flour from the leaves of each plant were weighed, submerged in $200 \mathrm{~mL}$ of distilled water or $200 \mathrm{~mL}$ of alcohol at $70 \%$ and allowed to sit for 48 hours at room temperature. Both solutions were subjected to steam stripping using a rotavapor (Büchi, $\mathrm{R}-114$, Switzerland), at a temperature of $70^{\circ} \mathrm{C}$ and at 40 rpm (Sánchez-Castellanos, 2006). Oils obtained were poured into amber glass bottles and stored in the refrigeration at $4^{\circ} \mathrm{C}$ until further usage (SánchezCastellanos, 2006).

\section{Inoculation of Petri dishes}

Petri dishes with eosin methylene blue agar were inoculated with $1 \times 10^{8} \mathrm{CFU} \mathrm{mL}-1$ of $E$. coli serotype $\mathrm{O} 2$ in the four directions using a swab. The correct density of the inoculum was performed using the method described by Sánchez et al. (2009). The Sensi-Discs had a diameter of $6 \mathrm{mM}$ and were made with Whatman paper number 2 and were distributed on the agar at no less than $22 \mathrm{mM}$ from each other and $14 \mathrm{mM}$ from the border of the Petri dish. Negative controls of distilled water and alcohol at 70\% were used for the extracts; petroleum ether was used in the essential oils. Positive controls were also used for essential extracts and oils, which consisted of commercial SensiDiscs (Whatman, Sigma-Aldrich, Mexico) loaded with Enrotrim at 10\% (enrofloxacin and trimethoprim), Macromycin E (colistin sulphate, erythromycin thocyanate and ethylenediamine dehydroiodide) and Doxy20 (doxycycline at 20\%). On each Sensi-Disc, 25 $\mu \mathrm{L}$ of extract (aqueous or alcohol at $70 \%$ ) or essential oil were poured, except on negative or positive control. The inoculated Petri dishes were incubated at $35^{\circ} \mathrm{C}$ for 18 hours for subsequent measurement.

\section{Phytobiotic activity measurement}

Agar diffusion method, described by KirbyBauer (Bauer et al., 1966), was used for measuring antimicrobial activity by presence or absence of the diameter in the inhibition zone (DIZ) of bacterial growth. The diameters were measured on the back of the Petri dish, placed against a brilliant light, using a millimeter rule in angles of $120^{\circ}$. The average of three measures was reported (Koneman et al., 1991).

\section{In vivo test}

\section{Preparation of the strain}

E. coli strain was cultured on eosin methylene blue agar at $37^{\circ} \mathrm{C}$ for 24 hours. The obtained culture was centrifuged at 3,400xg for 15 minutes; subsequently, it was washed and resuspended in PBS (pH 7.4). Bacterial concentration was measured by spectrophotometer at $660 \mathrm{mM}$ and an absorbance of 0.8 , using a plate reader (Thermo Scientific, Multiskan GO, Germany).

\section{Ethical Considerations of the Study}

The management and care of the chickens were in accordance with Animal Research Ethics and following guidelines approved in official techniques of animal care and health in Mexico (Ley Federal de Sanidad Animal; articles 19 to 22), NOM-033-ZOO-1995: Humanitarian slaughter of domestic and wild animals, and the international guiding principles for biomedical research involving animals by the Council for International Organizations of Medical Sciences (CIOMS).

\section{Experimental animals}

A total of 50 Ross 308 male chickens, 35 days old, without vaccines, coming from a clean and safe zone, were distributed in five treatments with ten replicates each one (Table 1). Each treatment was located in 5 experimental pens of approximately $1.95 \mathrm{~m}^{2}$, each equipped with a gallon type waterer (JAT, Jalisco, México). The negative control group was located in a distant pen and isolated from the experimental shed equipped with sanitary rugs to avoid crosscontamination.

Table 1 - Distribution of chickens inoculated with avian E. coli serotype $\mathrm{O} 2$ and treated with extracts of leaves with phytobiotic properties.

\begin{tabular}{llll}
\hline Group & Treatment & Dose & Inoculated (E. coli) \\
\hline 1 & Piper auritum & $30 \mathrm{~mL}$ of extract at $10 \%$ & Yes \\
2 & Ocimum basilicum & $30 \mathrm{~mL}$ of extract at $10 \%$ & Yes \\
3 & Control & Without extract and without antimicrobial & Yes \\
4 & Control & Enrofloxacin at 10\% & Yes \\
5 & Control* & & No \\
\hline
\end{tabular}

*Negative control. 
Aguilar-Urquizo E, Itza-Ortiz MF, Sangines-Garcia JR, Pineiro-Vázquez AT, Reyes-Ramirez A, Pinacho-Santana B
Phytobiotic Activity of Piper Auritum and Ocimum Basilicum on Avian E. Coli

\section{Chicken inoculation}

After a period of adaptation of seven days in the experimental pens, chickens were inoculated with $0.5 \mathrm{~mL}$ of a bacterial suspension of $1 \times 10^{8} \mathrm{CFU} \mathrm{mL}-1$ of $E$. coli serotype $\mathrm{O} 2$ by intratracheal route, using 1 $\mathrm{mL}$ syringe (Kwaga et al., 1994; Yunis et al., 2002; Rawiwet \& Chansiripornchai, 2009).

\section{Extract administration}

Thirty $\mathrm{mL}$ of aqueous extract was orally administered to each chicken 36 hours post inoculation, using a $1 \mathrm{~mL}$ syringe without needle (Plastipak, México); subsequently, it was administered every morning until 24 hours before being humanely slaughtered.

\section{Evaluated variables}

Chickenswere fed a diet based on soybean-sorghum, free of antibiotics, fungicides and coccidiostats. Body weights were recorded at the beginning (36 days), at the moment of inoculation (42 days) and at the end of the trial (59 days). At the end of the trial, chickens were humanely slaughtered according to the Mexican Official Standard NOM 033-ZOO-1995. Immediately, bursa of Fabricious, liver, heart, kidney, lung, spleen and gastrointestinal track were weighed. Weights were recorded as relative percentage of body weight (Huff et al., 2006).

Mortality and morbidity were measured as: 1) mortality: for chickens who died during the first nine days postinoculation and showed postmortem lesions of colibacillosis; 2) morbidity: for chickens that survived inoculation until the trial ended and showed lesions of colibacillosis at necropsy (Rawiwet \& Chansiripornchai, 2009). The integrity of air sacs, lung, pericardium and liver was observed and histopathologic findings of only lung and liver were described (Kleven et al., 1972; Charleston et al., 1998).

\section{Isolation, identification and quantification of E. coli}

Samples (10 g) of lung, liver, heart and spleen were taken and ground according to the technique described by Willis et al. (2008). The pool was diluted in serials $(1: 10)$ in $0.1 \%$ of saline solution. Subsequently, 100 $\mu \mathrm{L}$ of each dilution was placed on Agar McConkey and incubated at $37^{\circ} \mathrm{C}$ for 24 hours for its subsequent bacterial quantification as CFU g-1 transformed to Log base 10 (Mitsche et al., 2004; Willis et al., 2008).

\section{Statistical analysis}

A completely randomized design was used to analyze the variables of the diameter of the inhibition zone of bacterial growth of five treatments. One chicken was considered as experimental unit and the percentages of relative weights of the organs were analyzed using Kruskal-Wallis test, previous transformation of percentual data to square root of arc sine (Dughetti \& De Carli, 1999). Only mortality was described. The differences between means were analyzed using Tukey test, considering significant an alpha of 0.05 (Mendahall, 1994). Data were analyzed using the statistical program SPSS v 15.0 for Windows.

\section{RESULTS AND DISCUSSION}

The aqueous extracts of $P$. auritum and $O$. basilicum had less bactericide effect than their alcoholic extracts at $4 \%$ levels. The aqueous extracts had a DIZ of 9.6 and $9.0 \mathrm{mM}$ while, in the alcoholic extracts, DIZ were of $16.4 \mathrm{mM}$ and $13.9 \mathrm{mM}$ for $P$. auritum and $O$. basilicum, respectively (Table 2 ).

The obtained results show that both plants inhibit E. coli growth; however, while using alcohol at $70 \%$ as solvent in the preparation of alcoholic extracts, DIZ increased due to high polarity of the alcohol that allows to obtain an extract whose chemical composition contains the greater part of the components of the plant, polar or not polar; allowing to obtain an extract with greater quantity of secondary metabolites with phytobiotic activity (Sharapin, 2000), compared to the low solubility of water before the hydrocarbon skeleton of some phytobiotic components found in aqueous extracts (Kalemba \& Kunicka, 2003). Authors such as Hernández et al. (2003), Adebolu \& Abiola,

Table 2 - Diameters of the inhibition zone of bacterial growth $(\mathrm{mM})^{1}$ of avian E. coli serotype O2, challenged with extracts of leaves with phytobiotic properties.

\begin{tabular}{|c|c|c|c|c|c|c|c|c|c|}
\hline & \multicolumn{2}{|c|}{ Aqueous Extract } & \multicolumn{2}{|c|}{ Alcoholic Extract } & \multicolumn{2}{|c|}{ Negative Control } & \multicolumn{3}{|c|}{ Positive Control } \\
\hline & $\mathrm{Pa}^{2}$ & $\mathrm{Ob}$ & $\mathrm{Pa}$ & $\mathrm{Ob}$ & $\mathrm{Ad}^{3}$ & $\mathrm{Al}$ & EN & DX & MM \\
\hline $4 \%$ & $9.6^{b} \pm 0.8$ & $9.0^{b} \pm 0.7$ & $16.4^{f g} \pm 0.9$ & $13.9^{\mathrm{ef}} \pm 1.7$ & $6.3^{\mathrm{a}} \pm 0.4$ & $10.1^{b c} \pm 1.0$ & $32.0^{k} \pm 1.2$ & $24.6 \pm 1.2$ & $30.2^{k} \pm 2.4$ \\
\hline $8 \%$ & $10.8^{\mathrm{bcd}} \pm 0.8$ & $10.7^{b c} \pm 0.7$ & $20.5^{h i} \pm 1.1$ & $16.5^{\mathrm{fg}} \pm 2.0$ & & & & & \\
\hline $12 \%$ & $11.7^{\mathrm{bcde}} \pm 0.7$ & $11.9^{\text {bcde }} \pm 0.4$ & $21.5^{\mathrm{hi}} \pm 1.6$ & $19.0^{g h} \pm 1.4$ & & & & & \\
\hline $16 \%$ & $13.1^{\mathrm{de}} \pm 0.9$ & $12.5^{\mathrm{cde}} \pm 0.8$ & $22.0 \pm 2.5$ & $22.1^{\mathrm{i}} \pm 1.4$ & & & & & \\
\hline
\end{tabular}

abcdefghijk Different literals in column indicate difference $(p>0.05)$. ${ }^{1}$ Values are represented as mean \pm S.D. ${ }^{2}$ Plant from which the extract was obtained, Pa: P. auritum, Ob: 0 . basilicum. ${ }^{3}$ Control: Negative, Ad: Pure distilled water, Al: Alcohol at 70\%; Positive, EN: Enrotrim 10\%, DX: Doxi20, MM: Macromycin. 
(2005) and Nwinyi-Obinna et al. (2009) report that the genera studied are potential source of components with phytobiotic properties, mainly against pathogenic bacteria such as E. coli, Salmonella typhimurium and Pseudomona aeruginosa.

The percentage of the extract is an important factor in phytobiotic activity in both plants, by

increasing concentrations DIZ was greater, due to greater quantity of bioactive components. Burt et al. (2007) report that E. coli 0157:H7 bacterial cell decreased gradually by increasing the concentration of carvacrol and $p$-cymene in the culture medium; both essential oils inhibited the synthesis of flagella; therefore, no more flagellated forms were observed.
The results of DIZ presented by the essential oils of $P$. auritum and $O$. basilicum are shown in Table 3. Smaller DIZ were obtained by petroleum ether (6.1 mM), which means that E. coli growth was not affected, while greater DIZ were for the antimicrobials Enrotrim at 10\% and Macromycin with 29.6 and 29.1 $\mathrm{mM}$, respectively. Phytobiotic activity of essential oils of both plants were similar ( $p>0.05$ ). The DIZ were 20.2 and 20.09 for $P$. auritum and $O$. basilicum, respectively. Such activity coincides with Adebolu and Adiola (2005) and Reshmi et al. (2010), who report that essential oils of Piper and Ocimum gender present phytobiotic properties before several microorganisms such as $S$. aureus, E. coli and S. typhi.

Table 3 - Diameter of the zone of inhibition of bacterial growth $(\mathrm{mM})^{1}$ of avian E. coli serotype O2, challenged with essential oils of leaves with phytobiotic properties.

\begin{tabular}{|c|c|c|c|c|c|}
\hline Plant & & & & & \\
\hline Piper auritum & Ocimum basilicum & $E P^{2}$ & $\mathrm{EN}^{3}$ & DX & MM \\
\hline $20.2^{b} \pm 3.9$ & $20.09^{b} \pm 1.9$ & $6.1^{\mathrm{a}} \pm 0.2$ & $29.6^{c} \pm 3.1$ & $23.6^{b} \pm 2.3$ & $29.1^{c} \pm 4.2$ \\
\hline
\end{tabular}

abcDifferent literals in the same row indicate difference $(p<0.05)$. 'Values represent the mean \pm S.D. ${ }^{2}$ Negative control, petroleum ether $25 \mu L .{ }^{3}$ Positive control, EN: Enrotrim, DX: Doxi20, MM: Macromicine.

At the beginning of the experiment and at the moment of inoculation, the birds had a similar weight $(p>0.05)$; however, at slaughter these were different $(p<0.05)$ (Table 4). There was no difference $(p>0.05)$ between the highest body weight recorded on chickens of group 1, inoculated and treated with $P$. auritum extract and chickens of group 4, inoculated and treated with Enrofloxacin at 10\%. Chickens inoculated and treated with $O$. basilicum had similar body weight ( $p>0.05)$ to those of negative control (group 5), but lower than the group of $P$. auritum extracts $(p>0.05)$. The difference in body weights recorded was due to chickens inoculated with $E$. coli, because of severe anorexia mainly caused by lesions in organs such as: liver, spleen, kidney and digestive system (Dunnington et al., 1991; Gomis et al., 1997; Huff et al., 2006).

Table 4 - Body weight of chicken inoculated with avian E. coli serotype O2, treated with extracts of leaves with phytobiotic properties.

\begin{tabular}{|c|c|c|c|}
\hline Treatments $^{1}$ & & Body weight ${ }^{2}$ & \\
\hline & Initial weight & Inoculation weight & Weight at slaughter \\
\hline Group 1 & $2118.30 \pm 110.29$ & $2703.00 \pm 148.34$ & $3439.00^{a} \pm 157.33$ \\
\hline Group 2 & $2081.40 \pm 109.35$ & $2748.50 \pm 131.61$ & $3390.50^{\mathrm{ab}} \pm 176.89$ \\
\hline Group 3 & $2126.50 \pm 143.90$ & $2630.50 \pm 294.62$ & $3160.00^{b} \pm 510.32$ \\
\hline Group 4 & $2133.60 \pm 196.26$ & $2754.00 \pm 224.39$ & $3426.00^{\mathrm{a}} \pm 295.17$ \\
\hline Group 5 & $2123.10 \pm 113.80$ & $2747.00 \pm 157.90$ & $3360.00^{\mathrm{ab}} \pm 145.27$ \\
\hline
\end{tabular}

${ }^{\mathrm{ab} D i f f e r e n t ~ l i t e r a l s ~ i n ~ t h e ~ s a m e ~ c o l u m n ~ i n d i c a t e ~ d i f f e r e n c e ~}(p<0.05)$. ${ }^{\top}$ Treatments, Group 1 and Group 2: inoculated with $E$. coli and extracts of $P$. auritum and $O$. basilicum, respectively, Group 3: inoculated with E. coli without extracts, Group 4: inoculated with E. coli and Enrofloxacin at 10\% y Group 5: negative control. ${ }^{2}$ Values are represented as mean \pm S.D.

With respect to relative weights of the organs (Table $5)$, there was a difference in liver weight $(p<0.05)$. The highest relative weight of the liver was recorded in group $3(2.58 \%)$ and the smallest in group $5(1.61 \%)$. In groups 1 and 2 treated with $P$. auritum and $O$. basilicum, respectively, the liver relative weight was superior $(p>0.05)$ to $2.0 \%$ and lower $(p<0.05)$ than in group 3, which suggests a hepatomegaly caused by colibacillosis. P. auritum and $O$. basilicum had a beneficial therapeutic effect on chickens, decreasing the inflammatory response caused by pathogenic stimulus reflected in lower weight of the liver, with regard to group 3 (negative control). Several protein groups are synthesized in the liver as response to microbial challenge that can increase the relative size of this organ, which allows the estimation of the intensity of an inflammatory response (Korver et al., 1998; Willcox \& Bodeker, 2000; Chávez et al., 2015). 
Table 5 - Relative weight (\%) of chicken organs inoculated with avian E. coli serotype O2, treated with extracts of leaves with phytobiotic properties.

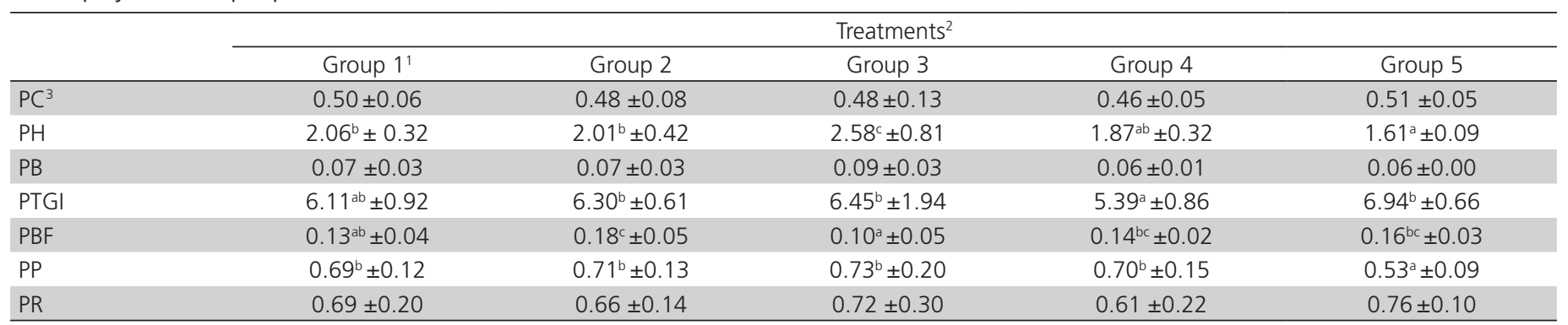

abcDifferent literals in the same row indicate difference $(p<0.05)$ 'Values are given in percentage $(\%)=\left[\left(\right.\right.$ organ weight/body weight) $X$ 100] and represent the mean $\pm S . D .{ }^{2}$ Treatments, Group1 and Group 2: inoculated with E. coli and extracts of $P$. auritum y 0 . basilicum, respectively, Group 3: inoculated with E. coli without extract, Group 4: inoculated with E. coli and Enrofloxacin at $10 \%$ and Group 5: negative control. ${ }^{3}$ Organs, heart= PC, Liver= PH, Spleen= PB, Gastrointestinal track= PTGI, Bursa of Fabricious= PBF, Lungs $=P P$, kidneys $=P R$.

Differences $(p<0.05)$ were found in the relative weight of the gastrointestinal track (WGIT). The greatest WGIT was recorded in group 5 (6.94\%), while the lowest was in group $4(5.39 \%)$; regarding groups 1 and 2, they had similar weights $(p>0.05)$. The relative weight of bursa of Fabricious (WBF) was greater $(p<0.05)$ in group $2(0.18 \%)$, followed by group $5(0.16 \%)$ and the lowest weight was in group $3(0.10 \%)$. The relative weights of lung $(\mathrm{WL})$ were only different $(p<0.05)$ in group $5(0.53 \%)$ with regards to the other groups, which means that inflammatory response in chickens inoculated with $E$. coli increased in WL, coinciding with Lau et al. (2010), who reported that chicken inoculated with E. coli 078:K80 showed higher weight $(p<0.05)$ in lungs compared to those not inoculated. It is important to mention that the route of inoculation was intratracheal, favoring lesions originated in the respiratory system.
The quantification of CFU ( $\left.\log _{10}\right)$ of $E$. coli isolated from organs (Table 6) was greater $(p<0.05)$ in the lungs of group 4 with Enrofloxacin at 10\%, bacterial growth can be translated as a possible resistance to the use of some antimicrobials and where in field $E$. coli has already been reported resistant to this product (Itza-Ortiz, 2018 personal communication). The lowest concentration of $E$. coli was observed in groups 2 and 1 , regarding the other groups $(p<0.05)$; the aforementioned supports phytobiotic activity of $P$. auritum and $O$. basilicum extracts on avian $E$. coli serotype $\mathrm{O} 2$.

It is possible that secondary metabolites present in $P$. auritum extracts or oils, such as safrole, besides synergism with other substances as thymol, carvacrol, myristicin, linalool, borneol, camphor, cineol, methyl eugenol and a wide variety of benzene components, are inhibiting bacterial growth (Domínguez et al., 1962;

Table 6 - Concentration ( $\log _{10}$ CFU g ${ }^{-1}$ ) of avian E. coli serotype $\mathrm{O} 2$ in pool of heart, liver and spleen, and lungs of inoculated chicken and treated with extracts of leaves with phytobiotic properties.

\begin{tabular}{|c|c|c|c|c|c|}
\hline & \multicolumn{5}{|c|}{ Treatments² } \\
\hline & Group 1 & Group 2 & Group 3 & Group 4 & Group 5 \\
\hline Pool & $4.06 \pm 0.86^{1}$ & $2.64 \pm 0.47$ & $5.75 \pm 3.03$ & $6.03 \pm 2.87$ & $0.00 \pm 0.00$ \\
\hline Lungs & $3.92 \pm 0.97^{a b}$ & $1.87 \pm 0.87^{a}$ & $6.32 \pm 1.48^{b c}$ & $7.36 \pm 1.59^{c}$ & $0.00 \pm 0.00$ \\
\hline
\end{tabular}

abcDifferent literals in the same row indicate difference $(p<0.05)$. 'Values represent the mean \pm S.D. ${ }^{2}$ Treatments, Group1 and Group 2 : inoculated with $E$. coli and extract of $P$. auritum and $O$. basilicum, respectively, Group 3: inoculated with E. coli, without extract, Group 4: inoculated with E. coli and Enrofloxacin at $10 \%$ and Group 5: negative control.

Oliveira et al., 2004). However, between phytobiotic extracts studied, the smallest growth of $E$. coli was obtained in $O$. basilicum, due to its active components, such as: $\beta$-linalool, estragole, linalool, 4-allyl anisole and eugenol; besides having phenolic acids derived from cinnamic acid and flavonoids (Acosta et al., 2003; Roldán et al., 2010), they form complexes with proteins and polysaccharides present in the external membrane of the cell, destabilizing the function of the membrane and cellular wall, causing microorganism death (Aguilar et al., 2007). Lee et al. (2003) report that isoprene, chemical unity of terpenoids, which derive in three phenols, with phytobiotic properties: thymol, carvacrol and eugenol, can dissociate the external membranes of Gram negative bacteria, such as $E$. coli and S. typhimurium.

There was higher frequency of aerosaculitis (Table 7) in chickens inoculated with E. coli, because the route of inoculation was intratracheal. As shown, it was more severe in group 3. Aerosaculitis observed in group 3, 
Table 7 - Morbidity of chickens inoculated with avian E. coli serotype O2, and treated with extracts of leaves with phytobiotic properties.

\begin{tabular}{|c|c|c|c|c|c|}
\hline \multirow[b]{2}{*}{ Sign } & \multicolumn{5}{|c|}{ Treatments $^{1}$} \\
\hline & Group 1 & Group 2 & Group 3 & Group 4 & Group 5 \\
\hline Aerosaculitis ${ }^{2}$ & $8 / 10$ & $7 / 10$ & $10 / 10$ & $8 / 10$ & $0 / 10$ \\
\hline Pericarditis & $4 / 10$ & $3 / 10$ & $7 / 10$ & $4 / 10$ & $0 / 10$ \\
\hline Perihepatitis & $4 / 10$ & $4 / 10$ & $7 / 10$ & $4 / 10$ & $0 / 10$ \\
\hline
\end{tabular}

'Treatments, Group1 and Group 2: inoculated with E. coliand extract of $P$. auritum and $O$. basilicum, respectively, Group 3: inoculated with E. coli without extracts, Group 4: inoculated with E. coli and Enrofloxacin at $10 \%$ and Group 5: negative control. ${ }^{2}$ Number of positive chickens with signs against number of chickens studied, is shown.

coincides with the reported by Lau et al. (2010), who indicate that $100 \%$ of inoculated chickens with $E$. coli serotype 078 showed this pathology. Presence of pericarditis and perihepatitis indicate a systemic infection and it was similar in groups 1 to 4; similar data were reported by Lau et al. (2010), in presence of pericarditis and perihepatitis in chicken inoculated with E. coli serotype 078:K80. Likewise, Rawiwet and Chansiripornchai (2009) report greater incidence of aerosaculitis than pericarditis and perihepatitis in chicken inoculated with $E$. coli serotype 078 .

Mortality in group 3 was 20\%, 10\% for group 2 and for the other groups (1, 4 and 5$)$ there was no mortality; mortality rate of field, caused by $E$. coli infection could be 10\% (Shane, 1981; Wray et al., 1996).

Histological lesions were more severe in group 3 than in groups 1, 2 and 4. Lung parenchyma showed multiple granulomas with necrotic center located in the lumen, surrounded by heterophils, lymphocytes, macrophages and giant cells (Figure 1); the aforementioned was not observed in groups 1 and 4; being less frequent in group 2. Air capillaries were more thickened in group 1. Histological findings suggest a restorative process of the damaged tissue; mainly in group 3, where necrotic tissue is being replaced by granulation tissue. Also, there is an immunological response, due to the presence of giant cells, macrophages, lymphocytes and few heterophils (Woolcock, 1979; Ridell, 1987). Heterophils are cells whose main function is the phagocytosis of several particles such as bacteria and other microorganisms (Banks, 1996), the lowest amount observed of granulation, can be due to the fact that necropsy of chickens was performed nine days after inoculation and heterophil infiltration occurs in early infections, in the first 48 hours post inoculation (Barnes et al., 2003).

Plant extracts with phytobiotic activity can act in the same manner as GPA, preventing immunological stress and its metabolic changes caused by the bacterial inoculum preventing immune activation (Roura et al., 1992). It is important to mention that there were
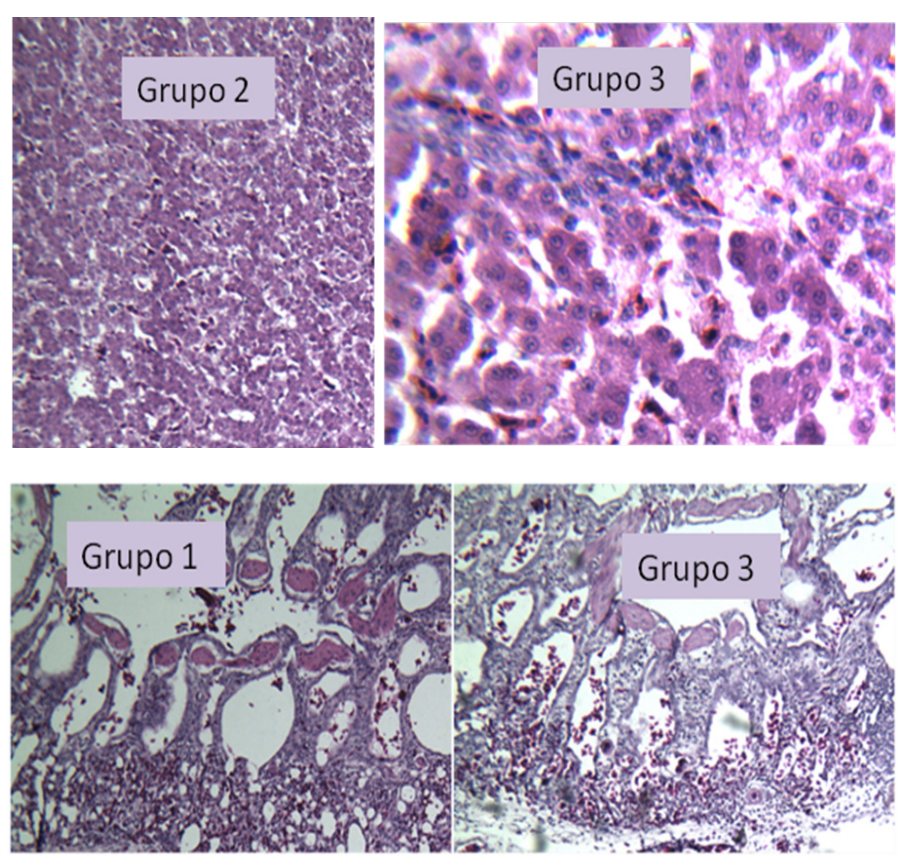

Figure 1 - Histological section of liver of Group 2 (chickens challenged with $E$. coli $\mathrm{O} 2$ and treated with extracts of $\mathrm{O}$. basilicum) and Group 3 (chickens challenged with E. coli 02 and untreated).

lesions not associated with $E$. coli, but to a mixture of etiological agents; especially in the respiratory track, where an inflammation can respond to an unlimited number of infectious agents (Barnes et al., 2003). The lesions observed in the liver of group 2 had the largest organization of hepatocyte cords in the hepatic parenchyma, possibly due to the therapeutic effect of $O$. basilicum extracts. Moderate multifocal hepatic lipidosis was observed in groups 1 and 2; group 3 showed mild multifocal. Hepatic lipidosis is caused by micotoxins in food, not by E. coli (Ridell, 1987); which means that chickens in group 3 had lower amount of food intake.

\section{CONCLUSION}

Extracts of the leaves of $P$. auritum and $O$. basilicum had phytobiotic activity on $E$. coli; with concentration higher than $8 \%$ and DIZ was observed above $10 \mathrm{mM}$. The solvent used in the extraction of active components of the plant can be an important factor in its activity, 


\section{Phytobiotic Activity of Piper Auritum and Ocimum Basilicum on Avian E. Coli}

since larger DIZ were obtained with the alcoholic extracts; in addition to this, the aqueous extract at $10 \%$ of $P$. auritum promoted food intake, reflecting a weight similar to commercial antimicrobial, which decreased the severity of the infection. Total $E$. coli count in lungs, heart, liver and spleen in chickens with $P$. auritum and $O$. basilicum extracts was lower than the obtained in chicken groups treated with commercial antimicrobial. Macroscopic lesions were observed in chickens with evidence of systemic illness, caused by bacterial inoculation; nevertheless, a greater number of repetitions are necessary to obtain the therapeutic effect caused by the extracts, since lesion classification according to its severity could be provided.

\section{REFERENCES}

Acosta M, González M, Araque M, Velazco E, Khouri N, Rojas L, et al. Composición química de los aceites esenciales de Ocimum basilicum L. var basilicum, O. basilicum L. var purpurenscens, O. ratissimum L., y O. tenuiflorum L., y su efecto antimicrobiano sobre bacterias multirresistentes de origen nosocomial. Revista de la Facultad de Farmacia 2003;45(1):19-24.

Adebolu TT, Abiola SO. Antimicrobial activity of leaf extracts of Ocimum gratissimum on selected diarrhoea causing bacteria in southwestern Nigeria. African Journal of Biotechnology 2005;4(7):682-684.

Aguilar CN, Rodríguez R, Gutierrez-Sanchez G, Augur C, Favela-Torres E, Prado-Barragán LA, et al. Microbial tannases: advances and perpectives. Applied Microbiology Biotechnology 2007;76:47-59.

Banks WJ. Histología veterinaria aplicada. $2^{\text {nd }}$ ed. Ciudad de México: Editorial el Manual Moderno; 1996.

Barnes HJ, Vaillancourt JP, Gross WB. Colibacillosis. In: Saif YM, editor. Diseases of poultry. $11^{\text {th }}$ ed. Ames: lowa State Press; 2003. p.631-656.

Bauer A, Kirby WMM, Sherris JC, Turck M. Antibiotic susceptibility testing by a standardized single disk method. American Journal of Clinical Pathology 1966;45:493-496.

Blanc V, Cortés P, Mesa R, Miro E, Navarro F, Llagostera M. Characterization of plasmids encoding extended-spectrum -lactamase and CMY-2 in Escherichia coli isolated from animal farms. International Journal of Antimicrobial Agents 2007;31(1):76-78.

Burt S. Essential oils: their antibacterial properties and potential applications in foods - a review. International Journal of Food Microbiology 2004;94:223-253.

Burt SA, Van der Zee R, Koets AP, Graaff AM, Van Knapen F, Gaastra W, et al. Carvacrol induces heat shock protein 60 and inhibits synthesis of flagellin in Escherichia coli 0157:H7. Applied and Environmental Microbiology 2007;73(14):4484-4490.

Burt SA, Vlielander R, Haagsman HP, Veldhuizen EJA. Increase in activity of essential oil components carvacrol and thymol against Escherichia coli 0157:H7 by addition of food stabilizers. Journal of Food Protection 2005;68(5):919-926.

Charleston B, Gate JJ, Aitken IA, Stephan B, Froyman R. Comparison of the efficacies of three fluoroquinolone antimicrobial agents, given as continuous or pulsed-water medication, against Escherichia coli infection in chickens. Antimicrobial Agents and Chemotherapy 1998;42(1):83-87.
Chávez L, López A, Parra JE. La inclusión de cepas probióticas mejora los parámetros inmunológicos en pollos de engorde. Revista CES Medicina Veterinaria y Zootecnia 2015;10(2):160-169.

Cook JA, Huggins MB, Ellis MM. Use of an infectious bronchitis virus and Escherichia coli model infection to assess the ability to vaccinate successfully against infectious bronchitis in the presence of maternallyderived immunity. Avian Pathology 1991;20:619-626.

Cortes RC. Escherichia coli: generalidades. México: Facultad de Medicina Veterinaria y Zootecnia, UNAM; 2008.

Cosentino S, Tuberoso CIG, Pisano B, Satta M, Mascia V, Arzedi E, et al. In vitro antimicrobial activity and chemical composition of Sardinian thymus essential oils. Letters in Applied Microbiology 1999;29:130 135.

Dho-Moulin M, Fairbrother JM. Avian pathogenic Escherichia coli (APEC). Veterinary Research 1999;30(2-3):299-316

Dixon RA. Phytoestrogens. Annual Review of Plant Biology 2004;55:225261.

Domínguez XA, Rojas P, Carza MD, Córdova JA. Preliminary study of 20 plants from the central territory of Quintana Roo, México. Revista Química Mexicana 1962;6:213-215.

Dorman HJD, Deans SG. Antimicrobial agents from plants: antibacterial activity of plant volatile oils. Journal of Applied Microbiology 2000;88:308-316.

Dozois CM, Dho-Moulin M, Brée A, Fairbrother JM, Desautels C, Curtiss III R. Relationship between the Tsh autotransporter and pathogenicity of avian Eschericha coli and localization and analysis of the Tsh genetic region. Infection and Immunity 2000;68:4145-4154.

Dughetti AC, De Carli DL. Utilización de distintos insecticidas y formulaciones en el control de Delia spp. en cebolla [informe técnico]. Provincia de Buenos Aires: Estación Experimental Agropecuaria INTA Hilario Ascasubi; 1999.

Dunnington EA, Siegel PB, Gross WB. Escherichia coli challenge in chicken selected for high or low antibody response and differing in haplotypes at the major histocompatibility complex. Avian Diseases $1991 ; 35(4): 937-940$.

Ewers C, Janssen T, Wieler LH. Avian pathogenic Escherichia coli (APEC). Berlin Munch Tierarztl Wochenschr 2003;116(9-10):381-95.

García RA, Leyva MA, Martínez MJR, Staschenko EE. Determinación de la composición química y actividad antioxidante in vitro del aceite esencial de Piper auritum Kunth (Piperacea) difundida en la Costa Colombiana. Scientia et Technica 2007;13(033):439-442

García-Compean L, Itza-Ortiz M, Ramón Ugalde JP, Sangines-García JR, Ortiz de la Rosa B, Zamora-Bustillos R, et al. Escherichia coli vaccine and laying hens mortality after a heat stress challenge in tropical climate. Journal of Animal and Veterinary Advance 2011;10(1):96-99.

Gomis SM, Watts T, Riddell C, Potter AA, Allan B. Experimental reproduction of Escherichia coli cellulitis and septicemia in broiler chickens. Avian Disease 1997:41:234-240.

Griggs PJ, Jacob PJ. Alternatives to antibiotics for organic poultry production. Journal Applied Poultry Research 2005;14:750-756.

Gupta MP, Arias DT, Williams NH, Bos R, Tattje DHE. Safrole, the main component of the essential oil from Piper auritum of Panama. Journal of Natural Products 1985;48(2):330-343.

Gurib-Fakim A. Medicinal plants: traditions of yesterday and drugs of tomorrow. Molecular Aspects of Medicine 2006;27(1):1-93. 
Hernández F, Madrid J, García V, Orengo J, Megías D. Influence of two plant extracts on broilers performance, digestibility, and digestive organ size. Poultry Science 2004;(83):169-174.

Horne SM, Pfaff-McDonough SJ, Giddings CW, Nolan LK. Cloning and sequencing of the iss gene from a virulent avian Escherichia coli. Avian Diseases 2000;44:179-184.

Huff WE, Huff GR, Rath NC, Donoghue AM. Evaluation of the influence of bacteriophage titer on the treatment of colibacillosis in broiler chickens. Poultry Science 2006;85:1373-1377.

Itza-Ortiz M. Personal communication. Ciudad Juárez: Universidad Autónoma de Ciudad Juárez; 2018.

Kalemba D, Kunicka A. Antibacterial and antifungal properties of essential oils. Bentham Science Publishers 2003;10(10):813-829.

Kalra YP. Handbook of reference methods for plant analysis. Boca Raton: CRC Press; 1998

Kato MJ, Furlan M. Chemistry and evolution of Piperaceae. Pure Applied Chemistry 2007;79:529-538

Kleven SH, King DD, Anderson DP. Airsacculitis in broilers from Mycoplasma synovie: effect on air-sac lesions of vaccinating with infectious bronchitis and Newcastle virus. Avian Disease 1972;16(4):915-924.

Koneman EW, Allen SD, Dowell VR, Sommers HM. Diagnóstico microbiológico. Ciudad de México: Editorial Médica Panamericana; 1991.

Korver DR, Roura E, Klasing KC. Effect of dietary energy level and oil source on broiler performance and response to an inflammatory challenge. Poultry Science 1998;77:1217-1227.

Kwaga JKP, Allan BJ, Van Den Hurk JV, Seida H, Potter AA. A carAB mutant of avian pathogenic Escherichia coli serogroup 02 is attenuated and effective as a live oral vaccine against colibacillosis in turkey. Infection and Immunity 1994;62(9):3766-3772.

Lattaoui N, Tantaoui-Elaraki A. Individual and combined antibacterial activity of the main components of three thyme essential oils. Rivista Italiana EPPOS 1994;13:13-19.

Lau GL, Sieo CC, Tan WS, Hair-Bejo M, Jalila A, Ho YW. Efficacy of a bacteriophage isolated from chickens as a therapeutic agent for colibacillosis in broiler chickens. Poultry Science 2010;89:2589-2596.

Lee KW, Everts H, Kappert HJ, Yeom KH, Beynen AC. Dietary carvacrol lowers body weight gain but improves feed conversion in female broiler chickens. Journal Applied Poultry Research 2003;12:394-399.

López-Casamayor EJ. Estudio fitoquímico y aproximación genética en especies de la sección Plinthine del Género Arenaria (Cariophyllaceae). Granada: Universidad de Granada; 2007.

Mahabir G. 270 plantas medicinales iberoamericanas. Santa Fe de Bogotá: Editorial Presencia; 1995

Mamoru K, Mujo K, Takehiko Y. Antifungal activity against food-borne fungi of Aspidistra elatior Blume. Journal of Agriculture and Food Chemistry 1996;44(1):301-303.

Mellata M, Dho-Moulin M, Dozois CM, Curtiss III R, Lehoux B, Fairbrother $J M$. Role of avian pathogenic Eschericha coli virulence factors in bacterial interaction with chicken heterophils and macrofages. Infection and immunity 2003;71:494-503.

Mendenhall W, Beaver RJ. Introduction to linear model and the design and analysis of experiments. In: Mendenhall W, editor. Introduction to probability and statistics. Belmont: Duxbury Press; 1994. p.244-251.
Mitsch P, Zitterl-Eglseer K, Kohler B, Gabler C, Losa R, Zimpernik I. The Effect of two different blends of essential oil components on the proliferation of Clostridium perfringens in the intestines of broiler chickens. Poultry Science 2004;83:669-675.

Monzote L, García M, Montalvo AM, Scull R, Miranda M. Chemistry, cytotoxicity and antileishmanial activity of the essential oil from Piper auritum. Memory Institute Oswaldo Cruz 2010;105(2):168-173.

Nakaruma CV, Nakaruma TU, Bando E, Melo AFN, Cortez DAG, DiazFilho BP. Antibacterial activity of Ocimum gratissimum L. essential Oil. Memory Institute Oswardo Cruz 1999;94:675-578.

Nwinyi-Obinna C, Chinedu-Nwodo S, Ajani-Olayinka O, Ikpo-Chinwe O, Ogunniran-Kehinde O. Antibacterial effects of extracts of Ocimum gratissimum and Piper guineense on Escherichia coli and Staphylococcus aureus. African Journal of Food Science 2009;3(3):77-81.

Oliveira LHW, Ehringhausm Ch, Yoshio PK. Genetic diversity of Pimenta longa genotypes (Piper spp., Piperaceae) of the Embrapa Acre germplasm collection. Genetics and Molecular Biology 2004;27(1):7482.

Oudhia P. Traditional medicinal uses in India. Journal of Planta Medical 2003;5(5):175-179.

Ramya DK, Karthikumar S, Jegatheesan K. Isolation of potential antibacterial and antioxidant compounds from Acalypha indica and Ocimum basilicum. African Journal of Plant Science 2010;4(5):163-166.

Rawiwet V, Chansiripornchai N. The efficacy of Escherichia coli AroA-Live vaccine in broilers against avian $E$. coli serotype $O 78$ infection. Thai Journal of Veterinary Medicine 2009;39(4):337-342.

Ridell C. Avian histopathology. Jacksonville: American Association of Avian Pathologists; 1987.

Regasini LO, Cotinguiba F, De-Araújo AM, Jorge KM, Scorzoni L, MendesGiannini MJ, et al. Antimicrobial activity of Piper arboreum and Piper tuberculatum (Piperaceae) against opportunistic yeasts. African Journal of Biotechnology 2009;8(12):2866-2870.

Reshmi SK, Sathya E, Suganya DP. Isolation of piperdine from Piper nigrum and its antiproliferative activity. African Journal of Pharmacy and Pharmacology 2010;4(8)562-573.

Rodríguez SEN. Uso de agentes antimicrobianos naturales en la conservación de frutas y hortalizas. Ra Ximhai 2011;7(1):153-170.

Roig JT. Plantas medicinales aromáticas o venenosas de Cuba. 5th ed. La Habana: Editorial Científico-Técnica; 1988.

Roldán LP, Díaz GJ, Duringer JM. Composition and antibacterial activity of essential oils obtained from plants of the Lamiaceae family against pathogenic and beneficial bacteria. Revista Colombiana de Ciencias Pecuarias 2010;23:451-461.

Roura E, Homedes J, Klasing KC. Prevention of immunologic stress contributes to the growth-permitting ability of dietary antibiotics in chicks. Journal of Nutrition 1992;122:2383-2390.

Sánchez $Y$, Pino O, Correa TM, Iglesia A, Naranjo E. Estudio químico y microbiológico del aceite esencial de Piper auritum Kunth (caisimón de anís). Revista de Protección Vegetal 2009;24(1):230-238.

Sánchez-Castellanos FJ. Extracción de aceites esenciales. Experiencia Colombiana. Annales do $2^{\circ}$ Congreso Internacional de Plantas Medicinales y Aromáticas; 2006 Oct 19-21; Vale del Cauca: Universidad Nacional de Colombia Sede Palmira; 2006.

Shane SM. Colisepticemia: cause, prevention in commercial broiler flocks. Poultry Digestion 1981;40:370-374. 
Sharapin N. Fundamentos de tecnología de productos fitoterapéuticos. Santa Fé de Bogotá: Quebecor-Impreandes; 2000.

Tequida-Meneses M, Cortez-Rocha M, Rosas-Burgos EC, López-Sandoval S, Corrales-Maldonado C. Efecto de extractos alcohólicos de plantas silvestres sobre la inhibición de crecimiento de Aspergillus flavus, Aspergillus niger, Penicillium chrysogenum, Penicillium expansum, Fusarium moniliforme y Fusarium poae. Revista Iberoamericana de Micología 2002;19:84-88.

Valsara T. Screening of indian medicinal plants for antimicrobial activity. Journal Ethnobiology 1994;35(3):275-283.

Vardar-Ünlü G, Candan F, Sökmen A, Daferera D, Polissiou M, Sökmen $M$, et al. Antimicrobial and antioxidant activity of the essential oil and methanol extracts of thymus pectinatus fisch. et mey. var. pectinatus (Lamiaceae). Jorunal Agriculture Food Chemistry 2003;51(1):63-67.

Woolcock JB. Bacterial infection and immunity in domestic animals. Amsterdam: St Elsevier Scientific Publishing; 1979. p.35-39;169-176.

Willcox ML, Bodeker G. Plant-based malaria control: research initiative on traditional antimalarial methods. Parasitology Today 2000;16 (6):220221
Willis WL, Goktepe I, Isikhuemhen OS, Reed M, King K, Murray C. The effect of mushroom and pokeweed extract on Salmonella, egg production and weight loss in molting hen. Poultry Science 2008;87:2451-2457.

Windisch W, Schedle K, Plitzner C, Kroismayr A. Use of phytogenic products as feed additives for swine and poultry. Journal of Animal Science 2008;86:E140-E148.

Witte W. Antimicrobial therapy in a Historical perspective. Acta Veterinaria Scandinavica 2000;93:7-16.

Wray C, Davies RH, Corkish JD. Enterobacteriaceae. In: Jordan FTW, Pattison M, editors. Poultry diseases. London: WB Saunders; 1996. p.9-43.

Yunis R, Ben-David A, Heller ED, Cahaner A. Antibody responses and morbidity following infection with infectious bronchitis virus and challenge with Escherichia coli, in lines divergently selected on antibody response. Poultry Science 2002;81:149-159 